\title{
DIAGNOSIS OF INFECTION BY FROZEN SECTION DURING REVISION ARTHROPLASTY
}

\author{
N. A. ATHANASOU, R. PANDEY, R. De STEIGER, D. CROOK, P. McLARDY SMITH \\ From the Nuffield Orthopaedic Centre and John Radcliffe Hospital, Oxford, England
}

We assessed the efficacy of intraoperative frozen-section histology in detecting infection in failed arthroplasties in 106 hips and knees.

We found inflammatory changes consistent with infection (an average of one or more neutrophil polymorphs or plasma cells per high-power field in several samples) in 18 cases; there was a significant growth on bacterial culture in 20 cases. Compared with the bacterial cultures, the frozen sections provided two false-negative results and three false-positive results (sensitivity, 90\%; specificity, 96\%; and accuracy, 95\%). The positive predictive value was $88 \%$, the negative value, $98 \%$.

These results support the inclusion of intra-operative frozen-section histology in any protocol for revision arthroplasty for loose components.

J Bone Joint Surg [Br] 1995;77-B:28-33.

Received 27 April 1994: Accepted after revision 29 June 1994

In failed arthroplasty, the distinction between aseptic loosening and infection is important both for the choice of surgical management and for the prediction of outcome. The surgeon must decide whether to resect the joint or to reimplant a new prosthesis in one or two stages. Two-stage revision arthroplasty has been shown to provide a better outcome after septic loosening than one-stage procedures allowing better preservation of bone stock and resulting in fewer rerevisions (Insall, Thompson and Brause 1983; Callaghan et al 1985; Walenkamp 1989; Antti-Poika et al 1990; Morscher, Babst and Jenny 1990; Wilson, Kelley and Thornhill 1990). When one-stage exchange is undertaken, the accurate diagnosis of infection is important since it may influence the extent of removal of foreign material.

N. A. Athanasou, PhD, MRCP, MRCPath, Consultant Pathologist R. Pandey, MS Orth, Dip Orth, Clinical Research Fellow

R. de Steiger, FRACS Orth, Joint Replacement Fellow, Honorary Consultant Orthopaedic Surgeon

P. McLardy Smith, MA. FRCS, Consultant Orthopaedic Surgeon

Nuffield Orthopaedic Centre NHS Trust, Windmill Road, Headington, Oxford OX3 7LD, UK

D. Crook, MRCP, MRCPath, Consultant Microbiologist

Microbiology Department. John Radcliffe Hospital, Headley Way, Oxford OX3 9DU, UK.

Correspondence should be sent to Dr N. A. Athanasou.

C1995 British Editorial Society of Bone and Joint Surgery 0301-620X/95/1927\$2.00
Early infections, although they may be difficult to diagnose, usually show some characteristic clinical and laboratory features (Rothman and Hozack 1988; Hamblen 1993). The late onset of low-grade infection, however, may give no specific clinical features to distinguish it from aseptic loosening. Several radiological and laboratory investigations, including bone and gallium scans, ESR, Creactive protein (CRP) levels and hip aspiration, have been used to distinguish septic from aseptic loosening, but have not proved reliable (Carlsson 1978; Buchholz et al 1981; Tehranzadeh, Schneider and Freiberger 1981; Pring et al 1986; Brause 1989; Gould, Potter and Bober 1990; Barrack and Harris 1993; Hamblen 1993; Kraemer et al 1993; Lieberman et al 1993).

A few previous studies have shown that histological examination, during operation, of cryostat sections of tissue can be diagnostic (Mirra et al 1976; Pizzoferrato, Fiori and Savarino 1981) but the reliability of this investigation has been questioned (Brause 1989; Fehring and McAlister 1991).

We aimed to determine the efficacy, sensitivity and specificity of frozen-section histological examination in distinguishing between septic and aseptic loosening during revision of hip and knee arthroplasties.

\section{MATERIALS AND METHODS}

From August 1991 to July 1993, specimens of tissues surrounding the prosthetic components of 106 hip and knee revision arthroplasties (104 patients) were submitted for frozen section. The clinical details of these cases are shown in Table I. We reviewed the case notes to determine age, gender, primary disease, duration of time from insertion of prosthesis to reoperation, and reasons for reoperation.

We calculated the sensitivity, specificity, accuracy, and the positive and negative predictive value of frozen-section diagnosis against the results of bacteriological culture (Armitage 1971; Barrack and Harris 1993). Sensitivity was the proportion of infected arthroplasties correctly identified by frozen-section examination (true-positive results divided by the sum of true-positive and false-negative results). Specificity was the proportion of non-infected hips correctly identified (true-negative results divided by the sum of true-negative and false-positive results). Accuracy was the ratio of true results (true-positive and true-negative results divided by the total number of results). The positive predictive value is the ratio of true results to the total number 
Table I. Clinical details of 104 patients undergoing 106 revision arthroplasties

\begin{tabular}{lll}
\hline & Hip & Knee \\
\hline Number of patients & 87 bilateral hip & 17 \\
& 1 patient operated twice
\end{tabular}

Mean age in years (range) 65.0 (33 to 92 ) 69.3 (54 to 88)

\begin{tabular}{lll} 
Right:left & $49: 40$ & $7: 10$ \\
Osteoarthritis & 79 & 13 \\
Rheumatoid arthritis & 2 & 2 \\
Other & $8^{*}$ & $2 \dagger$ \\
Arthroplasty & $\begin{array}{l}\text { Cemented } 63 \\
\text { Uncemented 22 } \\
\text { Hybrid 4 }\end{array}$ & $\begin{array}{l}\text { Unicompartmental 4 } \\
\text { Bicompartmental 13 }\end{array}$ \\
\hline
\end{tabular}

* hip dysplasia/CDH 4, ankylosing spondylitis 1, Paget's disease 1. Perthes' disease 1, fracture dislocation 1

+ Paget's disease 1, post-traumatic 1 inflammatory cells was very variable. We therefore assessed those sections which showed the most florid inflammatory changes. They were scanned to find areas of maximal inflammatory-cell infiltration and we then used a modification of the histological scoring method of Mirra et al (1976) to evaluate the extent of acute and chronic inflammatory-cell infiltration in a semiquantitative manner. At least ten high-power fields were examined for each area to provide an average score, for each, of neutrophil polymorphonuclear leucocytes (polymorphs), lymphocytes and plasma cells. The scoring was:

$$
\begin{aligned}
& 0=\text { absent } \\
& 1+=1 \text { cell per } 10 \text { high-power fields }(\times 400) \\
& 2+=1 \text { to } 5 \text { cells per high-power field } \\
& 3+=\text { more than } 5 \text { cells per high-power field }
\end{aligned}
$$

Bacteriology. At least two specimens of joint capsule and arthroplasty membrane were taken for microscopy and culture from each case. Specimens were transferred to

Table II. Summary of results for the diagnosis of infection by frozen-section in 106 arthroplasties

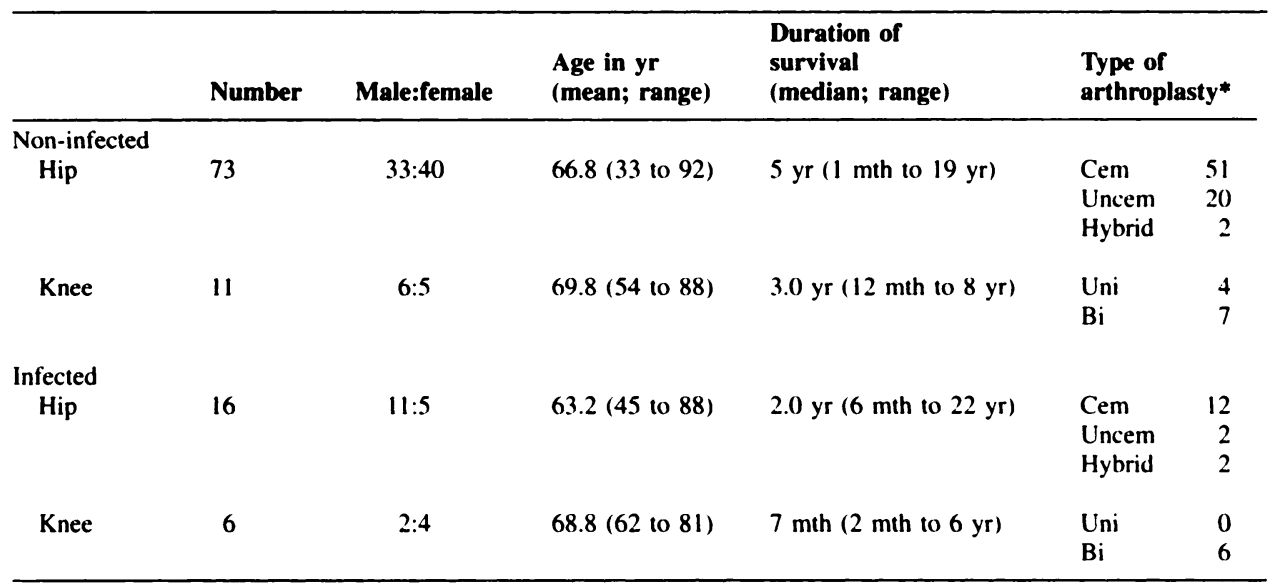

* Cem, cemented; Uncem, uncemented: Uni, unicompartmental: $\mathrm{Bi}$, bicompartmental

confirmed as infected by bacteriology; the negative predictive value is the ratio of true-negative results to the number of cases found not to be infected.

Histopathology. During hip revision, tissue was taken from the joint capsule and from the membrane at the interface between the bone and the prosthetic components. During knee revision, specimens were provided from the joint capsule and the membranes around the prosthetic components. In most cases, at least two specimens were taken from each of these tissues. All specimens were obtained before any perioperative antibiotics were given.

The tissue samples were snap-frozen in $\mathrm{CO}_{2} ; 5 \mu \mathrm{m}$ sections were cut and stained with haematoxylin and eosin, toluidine blue and Gram stains. The tissue specimens remaining were subsequently fixed in formalin and processed for paraffin sections, which were cut and stained in the same way.

The degree of infiltration with inflammatory cells varied considerably between capsular and membrane specimens. Even within individual tissue sections, the concentration of universal containers containing $3 \mathrm{ml}$ of peptone broth and ballotini (glass balls), and the tissue was dispersed as far as possible by shaking. Aliquots of the processed tissue were plated on to two blood-agar plates ( $5 \%$ horse blood), one aerobic and one anaerobic, and on to a chocolate-agar plate. The remainder of the tissue was transferred to tryptone soy broth, $0.1 \%$ agar, for enrichment culture. The aerobic blood-agar plates were incubated in air, the chocolate-agar plates in $10 \% \mathrm{CO}_{2}$, and the anaerobic plate in an anaerobic chamber. The aerobic blood-agar plate and chocolate plate were incubated for 48 hours. The anaerobic plates and enrichment broths were incubated for 5 days. Organisms were identified using routine laboratory methods (Balows et al 1991).

Isolates were considered to be significant if they grew on direct plating or if an indistinguishably similar strain grew on enrichment in more than one culture. Organisms were considered to be contaminants if distinguishable strains were isolated from different enrichment broths, and no growth occurred on direct plating. A single isolate of a 
strain from only one enrichment culture was not considered to be significant.

\section{RESULTS}

The results of the frozen-section diagnosis for all revision arthroplasties are summarised in Table II. There was no significant difference in gender, age or laterality between non-infected and infected patients. In the non-infected group ( 84 cases) the ESR was raised in six, the CRP in two and there was an increased uptake on the bone scan in five patients. In the 24 infected cases the ESR was raised in 11 of the 12 patients in which it was determined. The CRP was raised in three cases. Radiographs showed osteolysis around the prostheses in almost all the infected and noninfected cases.

The clinical and pathological details of all the cases diagnosed histologically or bacteriologically as infected are shown in Table III. Inflammatory changes consistent with infection were found in frozen sections in 21 cases; there was a significant bacterial growth in 20 cases. Assessed against the results of bacteriological culture, there were two false-negative results and three false-positive results from frozen-section histology. Sensitivity was approximately $90 \%$, specificity $96 \%$, accuracy $95 \%$ and the positive and negative predictive values were $88 \%$ and $98 \%$ respectively.

Non-infected cases. Of the 106 joints studied, 88 were diagnosed on frozen section as showing no inflammatory changes consistent with infection. No organisms were cultured from arthroplasty tissues derived from these joints. The frozen-section histology of almost all these specimens, from cases originally of osteoarthritis of the hip or knee, was characterised by the absence or extreme paucity of neutrophil polymorphs within sections of all tissues examined.

In five revision arthroplasties of the hip (two joint capsules and three femoral membranes) the tissues contained one or more isolated polymorphs but the average number in 10 high-power fields did not reach the $1+$ score. In these cases no definitive diagnosis was made and the case was discussed with the surgeon; the operative findings and the clinical history were then taken into account, and a decision taken to treat these cases as non-infected.

It is important to emphasise that only inflammatory cells within the joint capsule or arthroplasty membrane should be scored. Neutrophil polymorphs are not uncommon on the surface of arthroplasty tissues, as part of an area of blood staining, haemorrhage, or early thrombus formation. This appearance may be difficult to differentiate on frozen section from a focus of acute inflammatory exudate which is a common finding in infected arthroplasties. Infected cases, however, always have a heavy polymorph infiltrate within the tissues. Another less common source of confusion in specimens of an arthroplasty membrane covering bone is the presence of haemopoietic marrow-containing immature granulocytes and other myeloid elements.

In either the joint capsule or the arthroplasty membrane, scores of $1+$ or $2+$ lymphocytes were found in 36 noninfected cases ( 8 knees and 28 hips); these were most often seen as focal collections around small blood vessels. In isolation, this finding was not regarded as suspicious of infection. Routine histological examination of specimens derived from these cases, and on many others in which lymphocytes were not seen on frozen sections, showed that this finding was not uncommon in aseptic loosening. Three originally rheumatoid joints (one hip and two knees) showed $2+$ or $3+$ chronic inflammatory cells including $2+$ to 3+ lymphocytes and 1+ plasma cells. A heavy lymphocytic infiltrate $(2+)$ was also noted in five cases of aseptic loosening associated with heavy deposition of metal-wear particles in all arthroplasty tissues.

Infected cases. The median duration for which the prosthesis had been in situ in the infected cases was 24 months ( 2 to 264; Table II). In $52 \%$ of these cases, the prosthesis had been in for two years or less. The average age of this group of patients was 70 years (45 to 88). Of the 24 patients in the infected group, ten were reported to have had failure of primary wound healing at their first arthroplasty.

Tissue specimens from 21 cases (20 patients, one having two revision operations) were diagnosed by frozen-section histology as showing inflammatory changes consistent with infection, and all 21 were confirmed on routine histological examination. Organisms were grown on bacteriological culture from 18 of these cases, giving three apparent falsepositive reports for the frozen sections. Inadequate sampling was thought to account for two of these false-negative reports. Even when confirmation by bacteriological culture is used as the sole criterion, however, the sensitivity, specificity and accuracy of frozen-section diagnosis remain high, at $90 \%, 96 \%$ and $95 \%$ respectively. Of the 20 joints which yielded a significant bacteriological growth, 13 had coagulase-negative staphylococci, four Streptococcus species, one Enterococcus species, one methicillin-resistant Staphylococcus aureus, and one Corynebacterium species (Table III). This distribution of isolates is a typical spectrum of organisms for prosthetic joint infection (Bisno and Waldvogel 1994). Most of our cases were examples of late rather than early failure, and therefore the organisms associated with late infection, usually of low virulence, were predominantly cultured. This accounts for the isolation of few aggressive pathogens, such as aerobic Gram-negative bacilli or Staphylococcus aureus.

Details of the inflammatory cells noted on frozen-section histology of all bacteriologically confirmed cases are shown in Table III. In most cases $2+$ and $3+$ neutrophil polymorphs were noted, but two cases showed only $1+$ levels. These two cases, however, also showed $2+$ chronic inflammatory cells (lymphocytes and plasma cells) and one of them accounted for a false-negative diagnosis.

Infected tissues containing an infiltrate of neutrophil 
Table III. Clinical and pathological details of 23 cases diagnosed as infected by frozen-section histology and/or bacteriology

\begin{tabular}{|c|c|c|c|c|c|c|c|c|}
\hline Case & $\begin{array}{l}\text { Age } \\
\text { (yr) }\end{array}$ & Sex & $\begin{array}{l}\text { Prosthesis } \\
\text { type }\end{array}$ & $\begin{array}{l}\text { Right: } \\
\text { left }\end{array}$ & $\begin{array}{l}\text { Survival of } \\
\text { prosthesis }\end{array}$ & $\begin{array}{l}\text { Frozen-section diagnosis } \\
\text { Inflammatory cells noted* }\end{array}$ & Cultured organisms & Management \\
\hline \multicolumn{9}{|l|}{ Hips } \\
\hline 1 & 83 & $\mathbf{M}$ & Charnley & $\mathbf{R}$ & $20 \mathrm{yr}$ & $\begin{array}{l}\text { Infected: Gram-positive cocci } \\
\text { NP3+: L1+ }\end{array}$ & Group-G streptococcus & $\begin{array}{l}\text { 1-stage revision } \\
\text { (IV benzylpenicillin) }\end{array}$ \\
\hline 2 & 54 & $\mathbf{M}$ & Biomet & $\mathbf{R}$ & $2 \mathrm{yr}$ & $\begin{array}{l}\text { Infected } \\
\text { NP2+: L2+ }\end{array}$ & $\begin{array}{l}\text { Coagulase-negative } \\
\text { staphylococcus }\end{array}$ & $\begin{array}{l}\text { 2-stage revision } \\
\text { (IV vancomycin) }\end{array}$ \\
\hline 3 & 72 & $\mathrm{~F}$ & Thompson & L & $1 \mathrm{yr}$ & $\begin{array}{l}\text { Infected: Gram-positive cocci } \\
\text { NP3+: L2+ }\end{array}$ & $\begin{array}{l}\text { Coagulase-negative } \\
\text { staphylococcus }\end{array}$ & $\begin{array}{l}\text { 2-stage revision } \\
\text { (IV vancomycin) }\end{array}$ \\
\hline 4 & 53 & $\mathbf{M}$ & Charnley & $\mathbf{R}$ & $2 \mathrm{yr}$ & $\begin{array}{l}\text { Infected } \\
\mathrm{NP1+:} \text { PC1+: } \mathrm{L} 2+\end{array}$ & $\begin{array}{l}\text { Coagulase-negative } \\
\text { staphylococcus }\end{array}$ & $\begin{array}{l}\text { 2-stage revision } \\
\text { (IV penicillin) }\end{array}$ \\
\hline $5+$ & 50 & $\mathbf{M}$ & $\begin{array}{l}\text { Rotaloc cup: } \\
\text { Biomet stem }\end{array}$ & $\mathbf{L}$ & $6 \mathrm{mth}$ & $\begin{array}{l}\text { Infected } \\
\text { NP2+: L1+ }\end{array}$ & No growth & $\begin{array}{l}\text { 1-stage revision } \\
\text { (antibiotics stopped } \\
\text { after } 7 \text { days) }\end{array}$ \\
\hline 6 & 67 & $F$ & Charnley & $\mathbf{R}$ & $6 \mathrm{yr}$ & $\begin{array}{l}\text { Infected } \\
\text { NP3+: L1+ }\end{array}$ & Corynebacterium spp & $\begin{array}{l}\text { 2-stage revision } \\
\text { (IV vancomycin) }\end{array}$ \\
\hline 7 & 58 & $\mathbf{M}$ & Hinek & $\mathbf{R}$ & $2 \mathrm{yr}$ & $\begin{array}{l}\text { Infected } \\
\text { NP2+: L2+ }\end{array}$ & $\begin{array}{l}\text { Coagulase-negative } \\
\text { staphylococcus }\end{array}$ & $\begin{array}{l}\text { 2-stage revision } \\
\text { (IV vancomycin) }\end{array}$ \\
\hline 8 & 69 & $\mathbf{M}$ & Charnley & $\mathbf{R}$ & $6 \mathrm{yr}$ & $\begin{array}{l}\text { Infected } \\
\mathrm{NP} 2+: \mathrm{LI}+\end{array}$ & Enterococcus spp & $\begin{array}{l}\text { Girdlestone } \\
\text { (IV vancomycin) }\end{array}$ \\
\hline 9 & 45 & $\mathbf{M}$ & Charnley & $\mathbf{R}$ & $10 \mathrm{yr}$ & $\begin{array}{l}\text { Infected } \\
\text { NP3+: L2+ }\end{array}$ & $\begin{array}{l}\text { Coagulase-negative } \\
\text { staphylococcus }\end{array}$ & $\begin{array}{l}\text { 2-stage revision } \\
\text { (multiple IV } \\
\text { antibiotics) }\end{array}$ \\
\hline 10 & 51 & $\mathbf{M}$ & $\begin{array}{l}\text { Rotaloc cup: } \\
\text { Biomet stem }\end{array}$ & $\mathbf{R}$ & $6 \mathrm{mth}$ & $\begin{array}{l}\text { Infected } \\
\text { NP3+ }\end{array}$ & Streptococcus bovis & $\begin{array}{l}\text { 2-stage revision } \\
\text { (IV flucloxacillin) }\end{array}$ \\
\hline 11 & 54 & $\mathrm{~F}$ & Chamley & $\mathrm{L}$ & $1 \mathrm{yr}$ & $\begin{array}{l}\text { Infected: Gram-positive cocci } \\
\text { NP3+: L2+ }\end{array}$ & $\begin{array}{l}\text { Coagulase-negative } \\
\text { Staphylococcus aureus }\end{array}$ & $\begin{array}{l}\text { Girdlestone } \\
\text { (IV vancomycin) }\end{array}$ \\
\hline 12 & 88 & $\mathbf{F}$ & Charnley & $\mathbf{R}$ & $22 \mathrm{yr}$ & $\begin{array}{l}\text { Infected } \\
\mathrm{NP} 2+\text { L2+: PC1+ }\end{array}$ & $\begin{array}{l}\text { Methicillin-resistant } \\
\text { Staphylococcus aureus }\end{array}$ & $\begin{array}{l}\text { Multiple IV } \\
\text { antibiotics }\end{array}$ \\
\hline $13+$ & 52 & $\mathbf{M}$ & $\begin{array}{l}\text { Rotaloc cup } \\
\text { Oxford stem }\end{array}$ & $\mathrm{L}$ & $18 \mathrm{mth}$ & $\begin{array}{l}\text { Infected } \\
\text { NP2+; L2+: PCl+ }\end{array}$ & $\begin{array}{l}\text { Coagulase-negative } \\
\text { staphylococcus }\end{array}$ & $\begin{array}{l}\text { 2-stage revision } \\
\text { (IV vancomycin) }\end{array}$ \\
\hline $14 \ddagger$ & 81 & $\mathbf{M}$ & Hinek & L & $6 \mathrm{mth}$ & $\begin{array}{l}\text { Infected } \\
\text { NP3+: L3+ }\end{array}$ & No growth§ & $\begin{array}{l}\text { Girdlestone } \\
\text { (IV cefuroxime) }\end{array}$ \\
\hline 15 & 81 & $\mathbf{M}$ & $\begin{array}{l}\text { Cemented cup: } \\
\text { Biomet stem }\end{array}$ & $\mathbf{R}$ & $4 \mathrm{yr}$ & $\begin{array}{l}\text { Infected } \\
\text { NP3+: L3+: PCl+ }\end{array}$ & No growthi & $\begin{array}{l}\text { Girdlestone } \\
\text { (IV cefuroxime) }\end{array}$ \\
\hline 16 & 54 & $\mathbf{F}$ & Charnley & $\mathbf{R}$ & $5 \mathrm{yr}$ & $\begin{array}{l}\text { Not infected } \\
\mathrm{L2}+: \text { PC2+ }\end{array}$ & $\begin{array}{l}\text { Alpha-haemolytic } \\
\text { streptococcus }\end{array}$ & $\begin{array}{l}\text { One-stage revision } \\
\text { (IV penicillin) }\end{array}$ \\
\hline \multicolumn{9}{|l|}{ Knees } \\
\hline 17 & 81 & $\mathrm{~F}$ & Stanmore & L & $6 \mathrm{yr}$ & $\begin{array}{l}\text { Infected } \\
\text { NP3+: L2+ }\end{array}$ & $\begin{array}{l}\text { Coagulase-negative } \\
\text { staphylococcus }\end{array}$ & $\begin{array}{l}\text { 2-stage revision } \\
\text { (IV vancomycin) }\end{array}$ \\
\hline 18 & 72 & $\mathbf{F}$ & $\begin{array}{l}\text { Biomet } \\
\text { AGC }\end{array}$ & $\mathbf{R}$ & $6 \mathrm{mth}$ & $\begin{array}{l}\text { Infected } \\
\text { NP3+: L2+ }\end{array}$ & $\begin{array}{l}\text { Coagulase-negative } \\
\text { staphylococcus }\end{array}$ & $\begin{array}{l}\text { 2-stage revision } \\
\text { (IV vancomycin) }\end{array}$ \\
\hline 19 & 68 & $\mathbf{M}$ & AGC & $\mathbf{R}$ & $4 \mathrm{yr}$ & $\begin{array}{l}\text { Infected } \\
\text { NP3+: L3+: PC3+ }\end{array}$ & $\begin{array}{l}\text { Coagulase-negative } \\
\text { staphylococcus }\end{array}$ & $\begin{array}{l}\text { 2-stage revision } \\
\text { (IV vancomycin) }\end{array}$ \\
\hline 20 & 65 & $\mathrm{~F}$ & $\begin{array}{l}\text { Biomet } \\
\text { AGC }\end{array}$ & $\mathbf{R}$ & $6 \mathrm{mth}$ & $\begin{array}{l}\text { Infected } \\
\text { NP3+: L3+: PC1+ }\end{array}$ & $\begin{array}{l}\text { Coagulase-negative } \\
\text { staphylococcus }\end{array}$ & $\begin{array}{l}\text { 2-stage revision } \\
\text { (IV flucloxacillin } \\
\text { and rifampicin) }\end{array}$ \\
\hline 21 & 80 & $\mathbf{M}$ & AGC & $\mathrm{L}$ & $7 \mathrm{mth}$ & $\begin{array}{l}\text { Infected } \\
\text { NP3+: L2+: PC2+ }\end{array}$ & Streptococcus & $\begin{array}{l}\text { 2-stage revision } \\
\text { (IV penicillin) }\end{array}$ \\
\hline 22 & 62 & $\mathbf{F}$ & AGC & $\mathbf{R}$ & $2 \mathrm{yr}$ & $\begin{array}{l}\text { Infected } \\
\text { NP3+: L1+ }\end{array}$ & $\begin{array}{l}\text { Coagulase-negative } \\
\text { staphylococcus }\end{array}$ & $\begin{array}{l}\text { 2-stage revision } \\
\text { (IV fucloxacillin) }\end{array}$ \\
\hline $23 \ddagger$ & 54 & $\mathbf{M}$ & $\begin{array}{l}\text { Biomet } \\
\text { AGC }\end{array}$ & $\mathbf{L}$ & $2 \mathrm{mth}$ & $\begin{array}{l}\text { Not infected } \\
\text { NPI +; L2+ }\end{array}$ & $\begin{array}{l}\text { Coagulase-negative } \\
\text { staphylococcus }\end{array}$ & $\begin{array}{l}\text { 2-stage revision } \\
\text { (IV vancomycin) }\end{array}$ \\
\hline
\end{tabular}

* NP = neutrophil polymorphs; L. lymphocytes; PC, plasma cells

† same patient, same hip: second loosening occurring 18 months later (see Results)

$\ddagger$ theumatoid arthritis patient

$\S$ preoperative antibiotics given: pus cells seen on microscopy

I pus noted grossly at time of surgery; pus cells on microscopy but no growth; developed staphylococcal septicaemia postoperatively 
polymorphs also generally contained an increased number of chronic inflammatory cells, mostly lymphocytes. Such cases were generally scored as $2+$, but in some of them neutrophil polymorphs so greatly predominated that only $1+$ lymphocytes were found. In the absence of rheumatoid disease, plasma cells were a good marker of infection, being noted in eight of the infected cases on frozen-section histology.

The most common histological picture seen on frozen section was inflamed granulation tissue and an inflammatory exudate covering arthroplasty tissues. Adequate sampling of each case and of each specimen proved essential since the inflammatory changes were often focal and not generalised. Both our false-negative results for frozensection histology resulted from examining insufficient material. When more material from these joints was examined by routine histology, focal areas containing $2+$ neutrophil polymorphs and $2+$ lymphocytes were found beneath the lining membrane with an inflammatory exudate covering part of the membrane. Other arthroplasty tissues showed more diffuse inflammatory infiltrate containing abundant neutrophil polymorphs. The inflammatory changes were usually most easily identified in the membranes around loose femoral stems.

We found histological changes of infection in three cases in which bacteriological investigation was negative. These cases did not represent simple false-positive results, since the positive histological diagnosis was strongly suspected clinically, but not supported by bacteriology. Case 5 was treated as an aseptic loosening and had a one-stage revision without antibiotic treatment. He had recurrent loosening of the femoral component 18 months later and at the second revision arthroplasty (case 13) both frozen-section histology and bacteriology confirmed the presence of infection. Case 14 also had a clinical course indicative of infection. Failure to isolate an organism may have been due to a preoperative course of antibiotics. Case 15 developed a septicaemia postoperatively and blood cultures grew a coagulase-negative staphylococcus.

\section{DISCUSSION}

Several authors have shown a high correlation between the presence of acute and chronic inflammatory cells in periprosthetic tissues and septic loosening (Charosky, Bullough and Wilson 1973; Mirra et al 1976; Pizzoferrato et al 1981; Pipino et al 1989), but there have been few detailed studies of the efficacy and reliability of frozen-section histological diagnosis. Mirra et al (1976) found a heavy infiltrate of acute inflammatory cells on frozen-section histology in all 15 cases with other evidence of infection, and reported absence of neutrophil polymorphs in 21 non-infected cases. Pizzoferrato et al (1981) studied a series of 85 hip arthroplasties and had ten false-negative diagnoses, but confirmed the utility of the histological criteria of Mirra et al (1976). Fehring and McAlister (1991), however, reporting a series of 107 revision operations, concluded that frozensection histology was not sufficiently sensitive to detect occult septic loosening. Similar conclusions have been reached for the value of histology (and bacteriology) of preoperative aspiration biopsies (Brause 1989; Gould et al 1990; Barrack and Harris 1993; Kraemer et al 1993).

Our results show that intraoperative frozen-section histology is reasonably efficient and reliable. In over 100 cases we had only three false-positive and two false-negative results. The histological grading of the number and type of inflammatory cells proposed by Mirra et al (1976) suggests five polymorphs per high-power field to be the cut-off point for the histological diagnosis of infection. Our results indicate that this number is too high, and we would have missed a number of cases of low-grade infection if this criterion alone had been applied. Once contaminatingsurface blood cells have been excluded, the finding of even a small number of neutrophil polymorphs should be regarded as highly suspicious. In non-rheumatoid patients, the presence of plasma cells also correlates with septic loosening.

We found that Gram staining for bacteria was positive in only four infected cases on frozen section, all of which showed a heavy, diffuse infiltrate of neutrophil polymorphs. This shows that the positive identification of an organism on frozen section should not be regarded as necessary for the diagnosis of septic loosening.

Frozen-section histology is a rapid and relatively inexpensive means of distinguishing between aseptic and septic loosening. Even when multiple or repeated samples require processing and examining, a frozen-section diagnosis can usually be provided to the surgeon within 15 to 30 minutes, in time for a change to be made in the planned surgical management. The results were accurate, sensitive and specific enough to be useful. Three cases with no clinical evidence of septic loosening were diagnosed as infected only on frozen-section and routine histology, no organism being isolated bacteriologically.

The importance of adequate sampling of all submitted periprosthetic tissues needs emphasis. Inflammatory changes were often focal within a single specimen, and only after several samples had been processed and examined could the diagnosis of infection be established. Divergent findings in different specimens of the joint capsule and arthroplasty membrane were particularly obvious in revision hip arthroplasties; in these the most florid inflammation was generally found in the femoral revision membrane. The failure to obtain representative tissue and the focal nature of inflammatory change, particularly in the joint capsule, may explain the low sensitivity reported by some authors (Pizzoferrato et al 1981; Brause 1989; Kraemer et al 1993).

We found that the period between the initial arthroplasty and the revision was less than two years in more than $50 \%$ of infected cases, and in fewer than $10 \%$ of the noninfected cases. Only 3 of the 20 bacteriologically-proven 
Table IV. Protocol for the diagnosis or exclusion of infection by frozen-section histology during revision arthroplasty

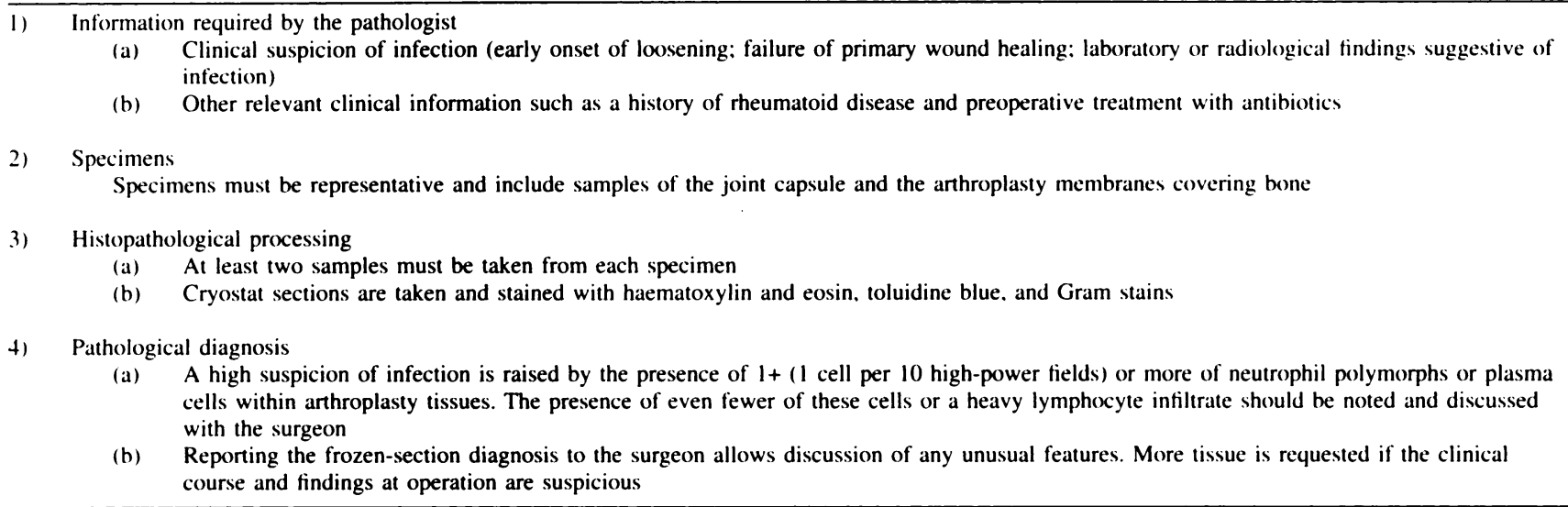

septic cases had retained their prosthesis for more than six years. For knee arthroplasties, only 2 of 7 cases had retained their original prosthesis for more than two years; most of the seven showed evidence of loosening within the first year. Ten of the 23 infected cases diagnosed by histology also had a history of wound infection after the primary arthroplasty. These and other clinical details, such as the presence of rheumatoid disease, should be known to the histopathologist before he gives an opinion on a frozen section.

We summarise our current procedures for the clinical and pathological evaluation of infection in joint arthroplasties in Table IV. This protocol provides a basis for the histological diagnosis of the presence or absence of infection, and helps to ensure appropriate surgical management of the failed arthroplasty.

The authors would like to thank Mrs L. Akers for typing the manuscript. Dr Pandey was supported by the Lord Nuffield Charitable Orthopaedic Trust and in part by the Wishbone Trust.

No benefits in any form have been received or will be received from a commercial party related directly or indirectly to the subject of this article.

\section{REFERENCES}

Antti-Poika I, Josefsson G, Konttinen Y, et al. Hip arthroplasty infection: current concepts. Acta Orthop Scand 1990;61:163-9.

Armitage P. Statistical methods in medical research. Oxford, etc: Blackwell Scientific. 1971.

Balows A, Hausler WJ Jr, Herrmann KL, Isenberg HD, Shadomy HJ. Manual of clinical microbiology. Fifth ed. Washington, DC: American Society of Microbiology, 1991.

Barrack RL, Harris WH. The value of aspiration of the hip joint before total hip arthroplasty. J Bone Joint Surg [Am] 1993;75-A:66-76.

Bisno AL, Waldvogel FA. Infections associated with indwelling medical devices. Second ed. Washington, DC: ASM Press, 1994.

Brause BD. Infected orthopedic prostheses. In: Bisno AL. Waldvogel FA. eds. Infections associated with indwelling medical devices. Second ed. Washington, DC: ASM Press, 1989:111-27.

Buchholz HW, Elson RA, Engelbrecht E, et al. Management of deep infection of total hip replacement. J Bone Joint Surg $[B r]$ 1981; 63-B:342-53.

Callaghan JJ, Salvati EA, Brause BD, Rimnac CM, Wright TM. Reimplantation for salvage of the infected hip: rationale for the use of gentamicin-impregnated cement and beads. In: Fitzgerald RH, ed. The Hip: Procs of 13th Scientific Meeting of the Hip Societv. St Louis, etc: CV Mosby, 1985:65-94.
Carlsson AS. Erythrocyte sedimentation rate in infected and non-infected total-hip arthroplasties. Acta Orthop Scand 1978:49:287-90.

Charosky CB, Bullough PG, Wilson PD Jr. Total hip replacement failures: a histological evaluation. J Bone Joint Surg (Am] 1973. 55-A:49-58.

Fehring TK, McAlister JA Jr. Frozen histologic section as a guide to sepsis in revision joint arthroplasty. Orthop Trans 1991:15:754.

Gould ES, Potter HG, Bober SE. Role of routine percutaneous hip aspirations prior to prosthesis revision. Skeletal Radiol 1990; 19:427-30.

Hamblen DL. Diagnosis of infection and the role of permanent excision arthroplasty. Orthop Clin North Am 1993:24:743-9.

Insall JN, Thompson FM, Brause BD. Two-stage reimplantation for the salvage of infected total knee arthroplasty. J Bone Joint Surg [Am] 1983;65-A:1087-98

Kraemer WJ, Saplys R, Waddell JP, Morton J. Bone scan. gallium scan and hip aspiration in the diagnosis of infected total hip arthroplasty. J Arthroplasty 1993;8:611-5.

Lieberman JR, Huo MH, Schneider R, Salvati EA, Rodi S. Evaluation of painful hip arthroplasties: are technetium bone scans necessary? J Bone Joint Surg [Br/ 1993:75-B:475-8.

Merkel KD, Brown ML, Fitzgerald RH Jr. Sequential technetium-99m HMDP-gallium 67 citrate imaging for the evaluation of infection in the painful prosthesis. J Nucl Med 1986:27:1413-7.

Mirra JM, Amstutz HC, Matros M, Gold R. The pathology of the joint tissues and its clinical relevance in prosthesis failure. Clin Orthop 1976:117:221-40.

Morscher E, Babst R, Jenny H. Treatment of infected joint arthroplasty. Int Orthop 1990:14:161-5.

Pipino F, Molfetta L, Resta L, et al. Bacteriological and histological study of forty loose cemented hip prostheses. Ital J Orthop Traumatol 1989:15:481-90.

Pizzoferrato A, Fiori F, Savarino L. Microbiological investigation of 161 cases of hip endo-arthroplasties failure. Chir Organi Mov 1981: 66:297-307.

Pring DJ, Henderson RG, Rivett AG, et al. Autologous granulocyte scanning of painful prosthetic joints. J Bone Joint Surg $\mid B r]$ 1986:68-B:647-52.

Rothman RH, Hozack WJ. Complications of total hip arthroplasty. Philadelphia, etc: W. B. Saunders Company. 1989.

Sanzén L, Carlsson ÅS. The diagnostic value of C-reactive protein in infected total hip arthroplasties. J Bone Joint Surg $[B r \mid$ 1989; 71-B:638-41.

Tehranzadeh J, Schneider R, Freiberger RH. Radiological evaluation of painful total hip replacement. Radiology 1981:141:355-62.

Walenkamp GH. Exchange arthroplasty for infected hip and knee prostheses. In: Coombs R, Fitzgerald RH. eds. Infection in the orthopaedic patient. London, etc: Butterworths. 1989:242-6.

Wilson MG, Kelley K, Thornhill TS. Infection as a complication of total knee-replacement arthroplasty: risk factors and treatment in sixtyseven cases. J Bone Joint Surg /Am/ 1990:72-A:878-83. 